\title{
Isolation and preliminary characterization of a pathogenic icosahedral deoxyribovirus from the catfish Ictalurus melas
}

\author{
F. Pozet ${ }^{1}$, M. Morand ${ }^{1}$, A. Moussa ${ }^{2}$, C. Torhy ${ }^{3}$, P. de Kinkelin ${ }^{3, *}$ \\ ${ }^{1}$ Laboratoire Vétérinaire DépartementaI, Bd T. Vernier BP 376, F-39016 Lons-le-Saunier Cedex, France \\ ${ }^{2}$ Centre National d'Etudes Vétérinaires et Alimentaires (CNEVA), Laboratoire de Pathologie Bovine, 31 Av. T. Garnier. \\ BP 7033, F-69342 Lyon Cedex 07, France \\ ${ }^{3}$ Institut National de la Recherche Agronomique (INRA), Unité de Virologie et d'Immunologie Moléculaires, Domaine de \\ Vilvert, F-78352 Jouy-en-Josas Cedex, France
}

\begin{abstract}
A virus was isolated from dead specimens of catfish Ictalurus melas originating from a pond in whach the whole catfish population had succumbed to an acute infection within a week. Diseased catfish showed clinical signs of oedema and haemorrhages while other fish species present in that pond remained healthy. The virus isolate grew well in Epithelioma papulosum cyprini (EPC), bluegill fry (BF2) and channel catfish ovary (CCO) cells at temperatures ranging from 15 to $25^{\circ} \mathrm{C}$. The virus formed tiny round plaques (diameter $400 \mathrm{um}$ ) under agarose overlays and the BF2 cells were the most sensitive for this assay. The infectivity of the catfish virus isolate was inhibited by chloroform treatment and its replication was suppressed by 5-iodo-2-deoxyuridine indicating the presence of lipid components and a DNA genome. Hexagonal virions with a diameter of 150 to $160 \mathrm{~nm}$, some of them surrounded by an external envelope, were seen by electron microscopy in the cytoplasm of infected EPC cells. These virions were morphologically similar to those of the Iridoviridae. Infection trials conducted in subadult and adult catfish demonstrated the strong pathogenicity of the new virus isolate and high levels of virus were detected in the kidney and spleen, inducing a dramatic necrotising spleno-nephritis and subsequently death of most of the fish. The infection trial substantiates the causative role of this virus isolate in the massive catfish mortality observed and constitutes the first record of an overt natural viral infection of $I$. melas.
\end{abstract}

\section{INTRODUCTION}

Several viruses have been isolated or observed by electron microscopy from siluriform fish (Wolf 1988), but only 3 of them have been demonstrated to be causative agents of systemic infections of juveniles with septicaemic clinical signs. The most conspicuous of these viruses is a herpesvirus, designated channel catfish virus (CCV) (Wolf \& Darlington 1971), which is responsible for significant losses of channel catfish Ictalurus punctatus in the USA. The 2 other viruses affect sheatfish Silurus glanis. They are spring viraemia of carp (SVC) virus (Fijan et al. 1982, Pasco et al.

\footnotetext{
- Addressee for correspondence
}

1987) and more recently, a remarkably pathogenic iridovirus-like agent isolated in Germany (Ahne et al. 1990).

The disease problems in channel catfish and sheatfish have drawn attention because certain catfish species are reared under intensive farming conditions which favours the accurence of communicable diseases. In contrast, little attention has been paid to the catfish Ictalurus melas, because this fish species readily adapts to detrimental environment conditions and thus seldom exhibits health troubles in the wild, and because it is a non-important species in Europe and is not considered to be worth the expense of diagnostic work. In fact, many sport fishery managers would be delighted to have some bioagressor specifically eradicate these catfish from certain bodies of water. 
The latter was the reason why, when a massive mortality affecting only catfish among the various fish species reared in a 7 ha pond in France occurred during summer 1990, fish samples were collected and sent to the Veterinary Laboratory (Lons-le-Saunier, France) for aetiological identification of the condition. This resulted in the isolation of a virus whose preliminary characterization indicated it is most probably a member of the family Iridoviridae. The isolate demonstrated high pathogenicity, and thus is believed to have had a causal role in the catfish mortality recorded in the field. Our results also show the increasing importance of iridoviruses in health problems encountered in fish farming as causative agents of systemic infections such as enzootic haematopoietic necrosis (EHN) virus (Langdon et al. 1986) and sheatfish iridovirus (Ahne et al. 1990), where in the past they were mainly known as agents of localized infections such as lymphocystis disease (Anders 1989), viral erythrocytic necrosis (Evelyn \& Traxler 1978) and more recently, viral epidermititis of white sturgeon Acipenser transmontanus (Hedrick et al. 1990).

Finally the isolation and identification of an iridovirus from Ictalurus melas raised questions regarding the possible relationship of this virus isolate to 2 other systemic iridoviruses isolated from fish. The results of that comparative study were reported in the previous issue of this journal (Hedrick et al. 1992).

\section{MATERIALS AND METHODS}

Fish. Dead catfish were collected at the site of the mortalities and transported on ice to the laboratory. They all possessed the gross signs of a septicaemic infection. Necropsy of 2 specimens, weighing 22 and $52 \mathrm{~g}$, revealed the presence of ascites and petechiae on viscerae and provided kidney and spleen samples for bacteriological and virological examinations. Catfish $(15$ to $70 \mathrm{~g})$ used for experimental infections were obtained directly from a pond located in a geographic area with no evidence of disease in catfish.

Fifty subadult and adult individuals were placed in a $300 \mathrm{l}$ aquarium fitted with aeration and water filtering devices, kept under observation for $6 \mathrm{wk}$ at 18 to $20^{\circ} \mathrm{C}$ and fed dry trout pellets at $1.5 \%$ of body $w t \mathrm{~d}^{-1}$. The water renewal rate was $20 \%$ of the total volume $\mathrm{wk}^{-1}$. Nineteen fish died or were sacrificed for laboratory examinations during the first $2 \mathrm{wk}$ of this acclimatization period leaving 31 fish available for experimental infection.

Bacteriological examination. Kidney and spleen homogenates were examined for bacteria as described previously (de Kinkelin et al. 1985), the medium for bacterial isolation being Trypticase soy agar.
Cells and virus isolation. The Epithelioma papulosum cyprini (EPC) (Fijan et al, 1983) cell line was used to isolate the virus. Two other cell lines, bluegill fry (BF2) (Wolf et al. 1966) and channel catfish ovary (CCO) (Bowser \& Plumb 1980), were also used for virus growth and assay. All 3 lines were grown in Stoker's medium (Stoker \& McPherson 1961) buffered with $0.16 \mathrm{M}$ Tris $\mathrm{HCl}$ at $\mathrm{pH} 7.4$ and supplemented with $10 \%$ tryptose phosphate, $10 \%$ fetal calf serum (FCS) and antibiotics (penicillin $100 \mathrm{IU} \mathrm{ml}^{-1}$ and dihydrostreptomycin $100 \mathrm{\mu g} \mathrm{m}^{-1}$ ). For virus production, the FCS content of the medium was reduced to $2 \%$ and the $\mathrm{pH}$ adjusted to 7.6 .

Pools of kidneys and spleens from 2 dead fish were ground in a mortar with pestle and prepared for inoculation of EPC cells as described by de Kinkelin et al. (1985). Incubation was conducted at $20^{\circ} \mathrm{C}$ and when the cytopathic effect (CPE) was complete, a $0.1 \mathrm{ml}$ aliquot of cell culture supernatant was diluted in 10 fold steps to a dilution of $10^{-7}$ and a second passage in EPC cells was made using aliquots of each dilution as inocula.

Virological monitoring during the infection trials was made by assessing the virus content in each dead or moribund individual by expressing the end point dilution at which CPE was observed in BF-2 cell monolayers grown in 24-well plastic plates and inoculated with $50 \mu \mathrm{l}$ aliquots of 10 -fold serial dilutions of homogenates from infected organs ( 2 wells dilution ${ }^{-1}$ ).

Electron microscopy. The EPC cells in a $25 \mathrm{~cm}^{2}$ plastic flask were inoculated with $10^{5}$ plaque forming units (pfu) of virus that had previously been subcultured twice in EPC cells. After $60 \mathrm{~h}$ at $20^{\circ} \mathrm{C}$, extensive CPE had occurred at which time the cells were removed from the flask and fixed for $24 \mathrm{~h}$ at $4{ }^{\circ} \mathrm{C}$ with $2 \%$ glutaraldehyde in $0.2 \mathrm{M}$ cacodylate buffer at $\mathrm{pH}$ 7.4. The fixed cells were rinsed in $0.2 \mathrm{M}$ cacodylate buffer and then post-fixed in $1 \%$ aqueous $\mathrm{OsO}_{4}$, dehydrated through an ethanol series, infiltrated and finally embedded in epoxy resin. Ultrathin sections were stained with $4 \%$ uranyl acetate and lead citrate. Examination was performed with a Jeol CX 100 electron microscope at $80 \mathrm{kV}$.

Preliminary characterization tests of the virus isolate. Plaque assays, under overlays of either $0.3 \%$ agarose (standard low $\mathrm{m}_{\mathrm{r}}$, Bio-Rad) or carboxymethylcellulose (sodium salt, Sigma), were carried out in each of the 3 fish cell lines. Susceptibility of the virus isolate to chloroform was tested by stirring a mixture (vol/vol) of infected cell culture fluid and chloroform at $4{ }^{\circ} \mathrm{C}$ for 4 or $16 \mathrm{~h}$. After centrifugation $(1500 \times \mathrm{g}$ for $15 \mathrm{~min}$ ) at $4{ }^{\circ} \mathrm{C}$, the infectivity of aliquots of serial 10 -fold dilutions from the aqueous phase was assayed on EPC cells. Untreated infected cell culture fluid was also titrated and served as a control. 
The type of nucleic acid of the virus isolate was established by studying virus multiplication in the presence of 5 iodo-2-deoxyuridine (IUdR). EPC cells, grown in 12 -well plates, were treated for $16 \mathrm{~h}$ at $20^{\circ} \mathrm{C}$ with Stoker's medium plus $2 \%$ FCS containing $50 \mu \mathrm{g}$ $\mathrm{ml}^{-1}$ IUdR. After rinsing with normal Stoker's medium, duplicate cell cultures were inoculated with each of the following virus strains: catfish virus isolate, frog virus 3 (FV3) and spring viraemia of carp virus (SVCV) at a multiplicity of infection $0.02 \mathrm{pfu}^{\mathrm{c}} \mathrm{cell}^{-1}$ and further incubated in IUdR supplemented Stoker's medium. Untreated EPC cells were inoculated similarly and served as controls.

Infection trial. The susceptibility of catfish was studied both following intramuscular injection (IM) of virus from EPC cell cultures or by virus released into the water by cohabitation with the virus-injected fish. In Aquarium 1, 2 lots of 6 fish each, marked by a cut on either the left or right operculum, received IM injections of $2 \times 10^{3}$ and $2 \times 10^{4}$ pfu of virus in a volume of $0.05 \mathrm{ml}$ respectively. A third lot of 7 healthy fish was placed into the same aquarium with the injected fish. Fish were examined for presence of the virus on Day 7 post-infection to check the success of our contamination protocol. Aquarium 2 harboured 2 lots of 6 mockinjected fish marked similar to those fish in Aquarium 1. Fish were also checked for virus after they died or when sampled as moribund fish (see Fig. 5). Prior to infection, fish from all lots were bled by puncture of the caudal vein and the resulting sera were stored at $-20{ }^{\circ} \mathrm{C}$. Similarly, blood from the only fish surviving infection was collected $60 \mathrm{~d}$ post-infection and the resulting serum processed and frozen at $-20^{\circ} \mathrm{C}$. On Days 13 and 14 post-infection, 3 moribund fish were sacrificed and their organs were divided for both virological and histological examination.

Histology. Portions of kidney, liver, spleen, gut, muscle, heart, encephalon and the entire gill were placed into both Bouin's fixative and neutral formalin and allowed to fix for $24 \mathrm{~h}$ at room temperature. They were then stored at $4^{\circ} \mathrm{C}$ for $1 \mathrm{wk}$ before being dehydrated and processed for paraffin embedding and sectioning. Tissue sections were stained with hematoxylin and eosin.

Serum neutralization tests. Neutralizing activity to the catfish virus isolate in sera from normal and infected survivor fish was tested by plaque assay in $\mathrm{BF} 2$ cells. Aliquots $(0.5 \mathrm{ml})$ of serial 2-fold dilutions of heat inactivated sera (lowest dilution 1:100) were mixed with $0.5 \mathrm{ml}$ aliquots of a virus suspension containing $2 \times 10^{3}$ pfu $\mathrm{ml}^{-1}$. After $1 \mathrm{~h}$ incubation at $20^{\circ} \mathrm{C}$, the virus-serum mixtures were plated onto $\mathrm{BF} 2$ cells and overlayed with agarose. A preliminary neutralisation test (NT) conducted in the presence or absence of fresh normal catfish serum had demonstrated that serum thermolabile factors were not required for this NT.

\section{RESULTS}

\section{Clinical signs of disease}

Dead fish from the infected pond displayed the classic clinical signs associated with infections by viruses with a tropism for haematopoietic tissues and the circulatory system. These included oedema, haemorrhages observable as petechiae around the pectoral and abdominal girdles and on viscerae, and ascites in the abdominal cavity. Gill pallor was evident in many fish. Experimentally infected fish lost their appetites 1 or $2 \mathrm{~d}$ before the onset of the gross signs of disease

\section{Bacteriology}

Aeromonas hydrophila was recovered from the organ homogenates tested but since the fish had been dead for more than $12 \mathrm{~h}$ by the time the bacteriological examination was conducted, this finding was not significant.

\section{Virus isolation in cell culture and preliminary virus characterization tests}

Cytopathic effects appeared in EPC cells $2 \mathrm{~d}$ after inoculation with supernatants of infected fish organ homogenates. Small dense greyish patches were first seen in the cell monolayer (Fig. 1) which developed into plaques with a border formed by a compact layer of spherical cells containing refractile cytoplasmic inclusions (Fig. 2a, b). At an inoculum dilution $1 \times 10^{-3}$ the entire cell monolayer showed CPE $3 \mathrm{~d}$ post-inoculation and the monolayer was completely detached from the plastic surface $2 \mathrm{~d}$ later. A second passage made in EPC cells, resulted in CPE at all inoculum dilutions up to $1 \times 10^{-6}$. Infected cells were then-sent to CNEVA's Laboratory for electron microscopy studies and INRA's Molecular Virology and Immunology Unit for other characterization studies and pathogenicity tests. For reference in our laboratory, the catfish virus isolate was designated No. 59-90.

Plaque assays using EPC cells under a $0.3 \%$ agarose overlay revealed virus concentrations up to $2 \times 10^{7} \mathrm{pfu}$ $\mathrm{ml}^{-1}+30 \%$ in infected cell culture supernatants during the second passage. Virus Isolate 59-90 also replicated in $\mathrm{BF}-2$ and $\mathrm{CCO}$ cells, within the temperature range 15 to $25^{\circ} \mathrm{C}$, providing virus yields identical to those from infected EPC cells. However, BF2 cells were found to be at least 10 times more sensitive to virus infection by plaque assay under agarose overlay than the 2 other cell lines tested. After $48 \mathrm{~h}$ incubation under an agarose overlay at $20^{\circ} \mathrm{C}$, the pinpoint plaques 

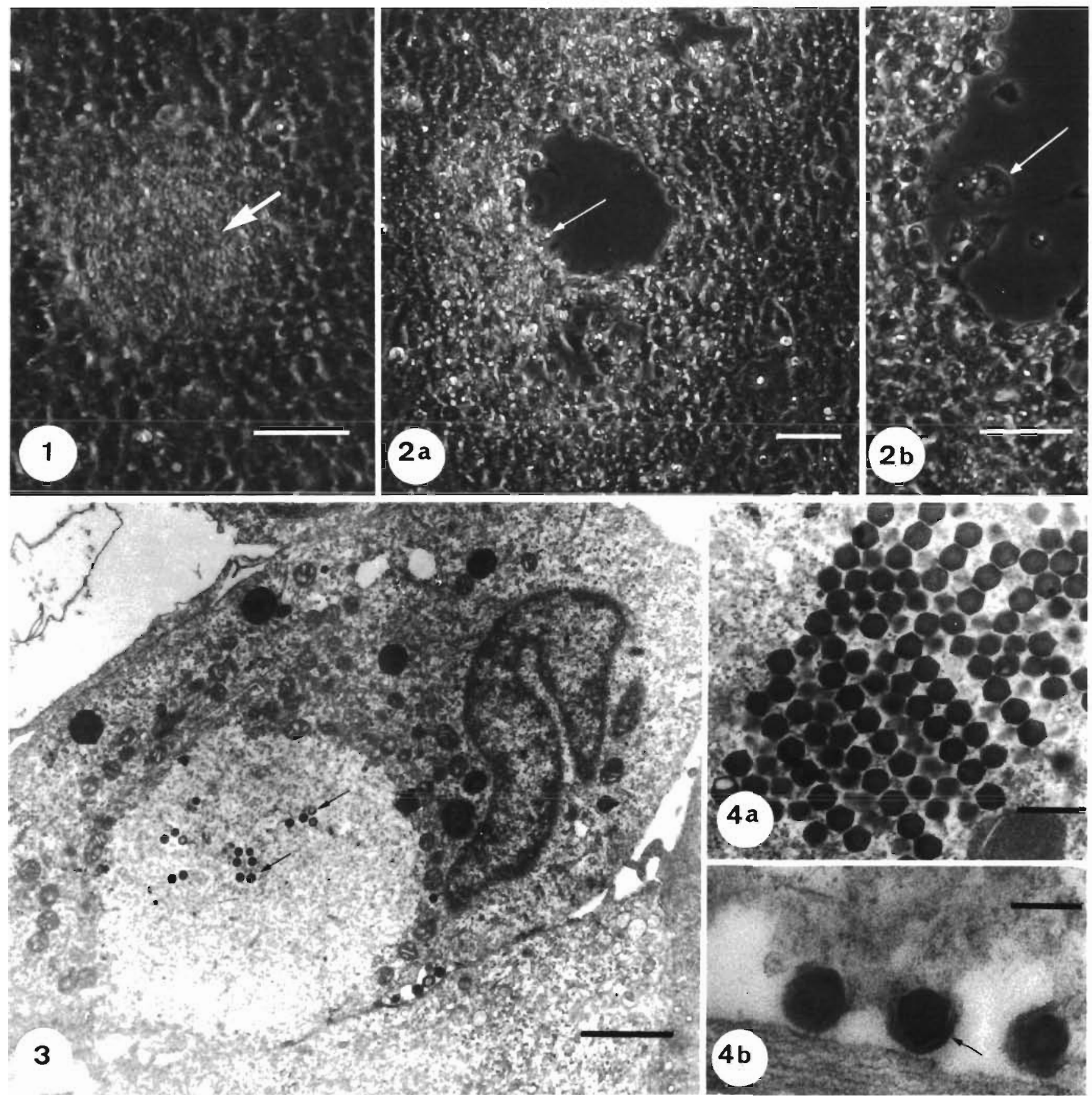

Figs. 1 to 4. Epithelioma papulosum cyprini cells infected with the catfish virus isolate and examined by phase contrast microscopy (Figs. 1 \& 2) and electron microscopy (Figs. $3 \& 4$ ). Fig. 1. First stage of plaque formation in the cell monolayer $36 \mathrm{~h}$ post-infection (arrow). Bar $=50 \mu \mathrm{m}$. Fig. 2. (a) Plaque $60 \mathrm{~h}$ post-infection at $20^{\circ} \mathrm{C}$. Its border is formed by a compact layer of spherical cells containing refractile cytoplasmic inclusions (arrow). Bar $=50 \mu \mathrm{m}$. (b) Higher magnification of a plaque border showing inclusion containing cells (arrow). Bar $=50 \mu \mathrm{m}$. Fig. 3. Clear round cytoplasmic inclusion containing viral nucleocapsids (arrows). Bar $=1.5$ $\mu \mathrm{m}$. Fig. 4. (a) Intracytoplasmic aggregate of viral nucleocapsids. Bar $=400 \mathrm{~nm}$. (b) Viral particles acquiring their envelopes (arrow) from the cytoplasmic membrane. $B a r=200 \mathrm{~nm}$

appeared clear and homogeneous in size with a mean diameter of 350 to $400 \mu \mathrm{m}$. Assays using methylcellulose overlays provided virus titres lower than those obtained under agarose and thus were less suitable for virus titration.
The infectivity of cell culture supernatants from the second passage of Isolate 59-90 was completely abolished after treatment with $50 \%$ chloroform for $16 \mathrm{~h}$ whereas after a $1 \mathrm{~h}$ treatment with $10 \%$ chloroform, it was reduced only by $60 \%$. The replication of plaque- 
purified Isolate 59-90 was dramatically suppressed by treatment of the EPC cells with IUdR (50 $\left.\mu \mathrm{g} \mathrm{ml}^{-1}\right)$ as was that of the DNA control virus FV3. Virus yields of the treated cultures were $<0.01 \%$ of those found in untreated 59-90 and FV3 cultures $\left(5 \times 10^{6}\right.$ and $2 \times 10^{6}$ $\mathrm{pfu} \mathrm{ml}^{-1}$ respectively). In contrast, the replication of the control RNA virus SVCV was not affected by treatment with $\operatorname{IUdR}\left(1.6 \times 10^{7} \mathrm{pfu} \mathrm{ml}^{-1}\right.$ in either treated or untreated cultures). The genome of catfish virus isolate is therefore most probably DNA.

\section{Electron microscopy}

In ultra-thin sections, the infected EPC cells displayed nuclear convolutions and hetero-chromatin. Round and clear cytoplasmic inclusions, devoid of any cytoplasmic organelles, contained both electron-dense and clear viral nucleocapsids (Fig. 3) and represent virus assembly sites. In the cytoplasm, nucleocapsids were also arranged as crystalline aggregates of hexagonal nucleocapsids (Fig. 4a). These nucleocapsids corresponded to icosahedral virions which further acquired an envelope either from intra-cytoplasmic membranes (not shown) or from the outer cytoplasmic cell membrane (Fig. 4b). Diameters of complete virions ranged from 150 to $160 \mathrm{~nm}$. These morphological data are consistent with those of other iridovirus-like agents of fish.

\section{Infection trial}

Fourteen catfish died during the infection trials at $18^{\circ} \mathrm{C}$. The onset of mortality occurred on Day 8 postinfection for a fish injected with $2 \times 10^{4} \mathrm{pfu}$. The last mortalities were recorded on Days 16 and 22 postinfection among 4 fish which had been infected via the water route (Fig. 5). Virus multiplication was demonstrated in all the fish since virus infectivity in organ homogenates reached at least $6 \times 10^{7} \mathrm{pfu}^{-1}$ in the processed kidney and spleen pools from 14 out of 18 fish. Only 1 catfish injected IM with $2 \times 10^{3}$ pfu survived. Serum from this fish, taken at 2 mo post-infection, neutralised Virus Isolate 59-90 at titre of 800 in a plaque assay, however the neutralising activity had a peculiar pattern. In a first step, the number of pfu presented a plateau corresponding to a reduction by about two-thirds up to dilution 1:400, then the plaque number dropped to $50 \%$ at a dilution of $1: 800$ and $30 \%$ at a dilution of $1: 1600$. Plaque reduction patterns given by sera collected from catfish of the same lot prior to virus infection showed only a slight decrease in plaque number ranging between 0 and $15 \%$ (Fig. 6).

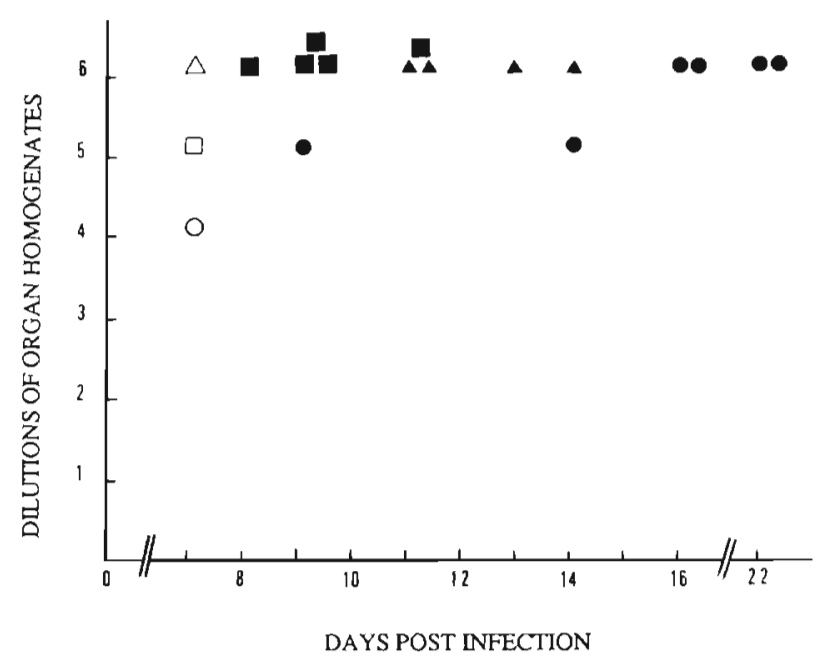

Fig. 5. Ictalurus melas. Experimental infection with catfish virus isolate at $20^{\circ} \mathrm{C}$. Assessment of the virus content in homogenates of kidney-spleen pools according to route of infection, date of sampling and clinical status of fish sampled. Triangles: $2 \times 10^{3}$ pfu (IM); squares: $2 \times 10^{4}$ pfu (IM); circles: water route (cohabitation). Open symbols: fish clinically normal at sampling; filled symbols: fish moribund or dead at sampling. Virus multiplication in fish is expressed as the end point dilution at which CPE occurs in BF2 cells inoculated with $50 \mu \mathrm{l}$ aliquots of serial 10 -fold dilutions of kidney-spleen homogenate. Dilution no. $1=1: 30$

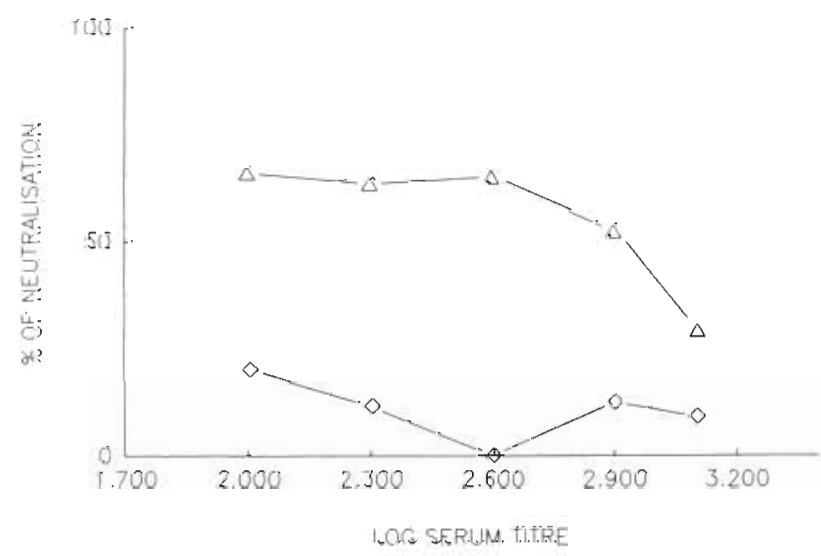

Fig. 6. Plaque reduction curves of the catfish virus isolate after neutralisation by serum from the one surviving fish $(\Delta)$ and by serum collected prior to infection $(\diamond)$. Virus dose employed was 130 pfu $0.1 \mathrm{ml}^{-1}$

\section{Histopathology}

Kidney tissues appeared to be the principal target for Virus Isolate 59-90. Cells from both interstitial tissue and tubules were degenerative and necrotic. This was also evident in the walls of blood vessels at various degrees of severity depending on fish. Most often, the haematopoietic structures were nearly destroyed 
(Fig. $7 \mathrm{a}$, b). These degenerative and necrotising lesions were also present in the spleen (Fig. 9) which was more or less reduced to its fibro-conjunctive frame whereas the liver displayed a dilatation of sinusoids due to a noticeable oedema (Fig. 10). Furthermore an extensive lamellar fusion and hyperplasia with obliteration of intralamellar spaces of the gill were observed (Fig. 8).

\section{DISCUSSION}

The virus isolated from catfish suffering from a haemorrhagic syndrome was found to be the causative agent of the massive mortality occuring in a pond. The correlation of virus multiplication, clinical signs, and histopathological lesions in the experimentally infected fish (even in those individuals infected by cohabitation)
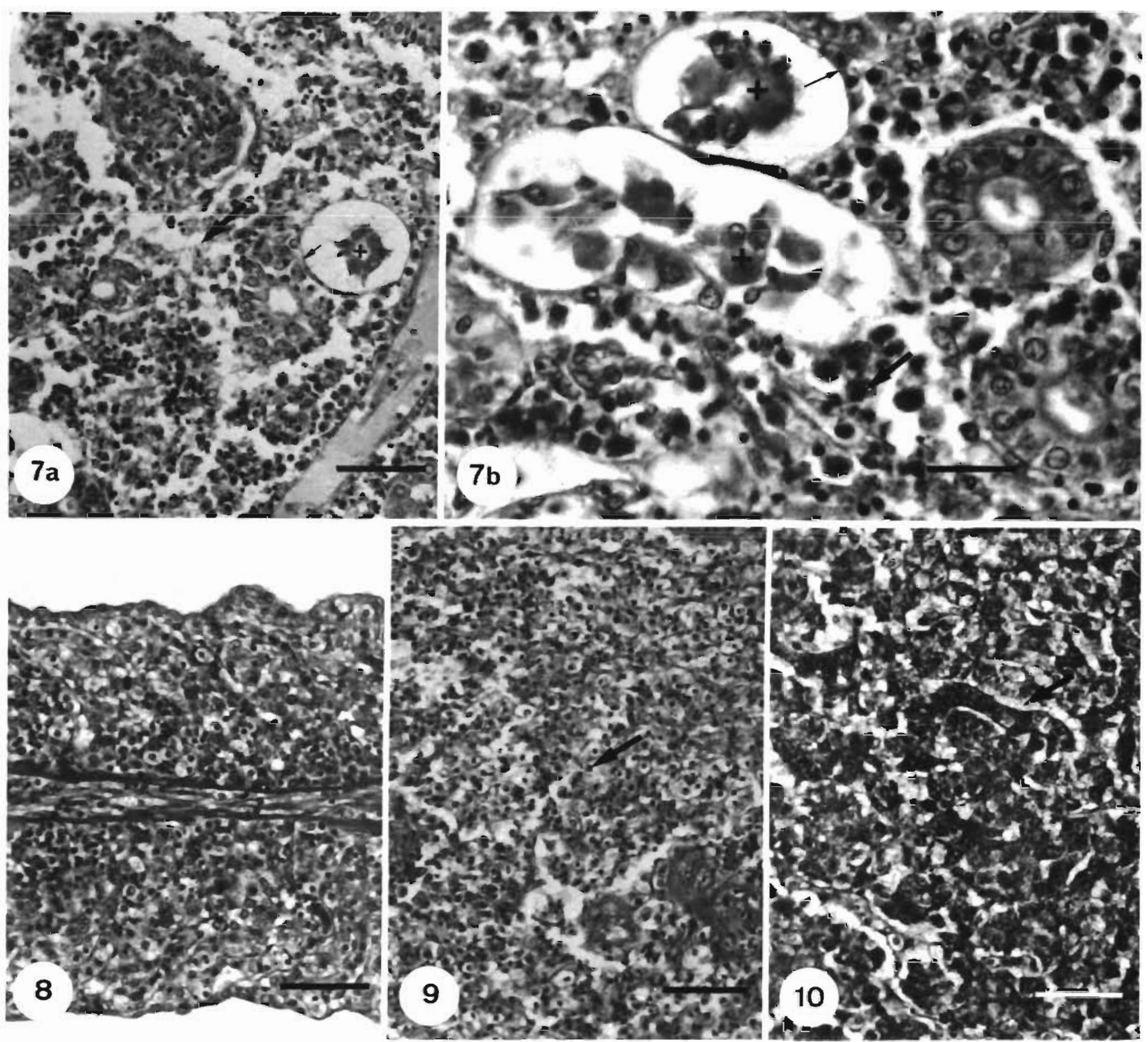

Figs. 7 to 10 . Ictalurus melas. Specimens infected with the catfish virus isolate and examined by light microscopy following $\mathrm{H} \& \mathrm{E}$ staining. Fig. 7. Necrotising nephritis affecting both the interstitial tissue (arrow) and the cells of proximal tubules which detach from the basal membrane (thin arrow) to form deeply stained cell aggregates (+). (a) Bar $=50 \mu m_{i}$ (b) bar $=20 \mu \mathrm{m}$. Fig. 8 . Gill showing an extensive lamellar fusion and hyperolasia with obliteration of interlamellar spaces. Bar $=50 \mu \mathrm{m}$. Fig. 9 . Diffuse necrotising splenitis (arrow). Bar $=50 \mu \mathrm{m}$. Fig. 10. Oedemateous hepatitis showing the dilatation of sinusoids (arrow). Bar $=50 \mu \mathrm{m}$ 
substantiate the viral aetiology of the disease observed. Furthermore, this constitutes the first record of a septicaemic viral infection of catfish Ictalurus melas. Despite the fact that the fish used for experimental infection were ordinary adult and subadult catfish, and not juveniles, which are usually used as test animals for demonstrating viral aetiologies, morbidity and mortality were high. The high degree of virulence of the catfish virus isolate for its host and the haemorrhagic nature of the disease can be attributed to the virus tropism for haematopoietic tissues as well as those of the circulatory and excretory systems. It is to be stressed that under field conditions overt viral infection appeared to strike specifically catfish and not other fish species present such as pike, perch and representatives of the family Cyprinidae. This host specificity, which suggested a viral aetiology, will be examined in more detail in the near future.

The fate of infection in fish surviving infection is unclear since results were available from only 1 survivor from the experimental infection. However, the serum from this fish had clearly acquired a neutralising activity after infection when compared to sera from the fish prior to use in the infection trial. The 2 -step neutralisation pattern could be due to the existence of 2 types of virions: one type being sensitive to neutralizing antibodies (NAb) because of its cell-derived envelope and the other one not sensitive because it was devoid of this envelope. Such duality of virions is known with members of Iridoviridae (Aubertin 1991) in which the envelope is not critical but enhances infectivity. It is thus likely that catfish NAb reacts with enveloped virions but not with unenveloped ones and that once the serum dilution is high enough, the total infectivity is restored. Based on its morphology (symmetry, size, type of envelope) and its inhibition by IUdR, the catfish virus isolates appear to belong to the family Iridoviridae. This family encompasses 5 genera (Aubertin 1991), 2 being dedicated to fish viruses, Lymphocystivirus and the goldfish virus group. Compared to lymphocystis virus, the catfish virus isolate is about twice as small, undergoes cytoplasmic instead of nuclear replication and induces a septicaemic haemorrhagic condition instead of a dermal fibroblastic hypertrophy. The catfish virus isolate resembles more closely the goldfish iridovirus (GFI) (Berry et al. 1983) in its size, cytoplasmic localisation of virus assembly in inclusions and cytocidal effect but in contrast to GFI it is highly pathogenic for its host species. Moreover GFI displays similarities with Frog Virus 3 (Berry et al. 1983). The catfish virus isolate also differs in size, target cells and pathogenicity from the white sturgeon iridovirus (Hedrick et al. 1990).

On the basis of its pathogenicity, morphology, and size, the catfish virus isolate seems most closely related to the sheatfish iridovirus and possibly to EHNV. All 3 of these viruses induce a haemorrhagic syndrome. However, in the absence of data on the antigenic properties of these viruses at the time our study was conducted, this hypothesis is presumptive. Results of a comparison of the protein structure and antigenic properties of these 3 viruses were published previously (Hedrick et al. 1992).

Acknowledgements. Mrs F. Branchard, D. Monge and C. Volatier are acknowledged for excellent technical assistance and D. Dumonteil for editorial assistance. We are indebted to R. Hedrick for helpful comments and criticisms in the preparation of this manuscript.

\section{LITERATURE CITED}

Ahne, W., Ogawa, M., Schlotfeldt, H.J. (1990). Fish viruses: transmission and pathogenicity of an icosahedral cytoplasmic deoxyribovirus isolated from sheatfish (Silurus glanis). J. vet. Med. B37: 187-190

Anders, K (1989). Lymphocystis disease of fishes. In: Ahne, W., Kurstak, E. (eds.) Viruses of lower vertebrates. Springer, Berlin, p. 141-160

Aubertin, A. M. (1991). Family Iridoviridae. In: Francki, R. J., Fauque, C. M, Knudson, D. L., Brown, F. (eds.) Classification and nomenclature of viruses. Arch. Virol. Suppl. 2: 132-136

Berry, E. S., Shea, T B., Gablicks, J. (1983). Two iridovirus isolates from Carassius auratus (L). J. Fish Dis. 6: 501-510

Bowser, P. R., Plumb, J. A. (1980). Fish cell lines: establishment of a line from ovaries of channel catfish. In Vitro 16: 365-368

Evelyn, T P. T., Traxler, G. S. (1978). Viral erythrocytic necrosis: natural occurence in Pacific salmon and experimental transmission. J. Fish Res. Bd Can. 35: 903-907

Fijan, N., Petrinec, Z, Sulimanovic, D., Zwillenberg, L. O (1971). Isolation of the causative agent from the acute form of infectious dropsy of carp. Vet. Arh. 41 (56): 125-138

Fijan, N., Sulimanovic, D., Béarzotti, M., Muzinic, D., Zwillenberg, L. O., Chilmonczyk, S., Vautherot, J. F., de Kinkelin, P. (1983). Some properties of the Epithelioma papulosum cyprini (EPC) cell line from carp (Cyprinus carpio). Annls Inst. Pasteur/Virol. 134 (E) : 207-220

Hedrick, R. P., Groff, J. M., McDowell, T., Wingfield, W H. (1990). An iridovirus intection of the integument of the white sturgeon Acipenser transmontanus. Dis. aquat. Org. 8: $39-44$

Hedrick, R. P., McDowell, T S., Ahne, W., Torhy, C., de Kinkelin, P. (1992). A comparison of three iridovirus-like agents associated with systemic infections of fish. Dis. aquat. Org. 13: 203-209

de Kinkelin, P., Michel, C., Ghittino, P. (1985). Précis de pathologie des poissons. Office International des Epizooties, Institut National de la Recherche Agronomique, Paris

Langdon, J. S., Humphrey, J. D., Williams, L. M., Hyatt, A. D., Westbury, H. A. (1986). First virus isolation from Australian. fish: an iridovirus-like pathogen from redfin perch, Perca fluviatilis L. J. Fish Dis. 9: 263-268

Pasco, L., Torchy, C., de Kinkelin, P. (1987). Infection expérimentale de l'alevin de silure (Siluris glanis L.) par le virus de la virémie printanière de la carpe (VPC). Bull. Pisc. 307: 84-88 
Stoker, M., McPherson, I. (1961). Studies on transformation of hamster cells by polyoma virus in vitro. Virology 14 : $359-370$

Wolf, K. (1988). Fish viruses and viral diseases. Cornell Univ. Press, Ithaca

Responsible Subject Editor: F. M. Hetrick, College Park, Maryland. USA.
Wolf, K., Darlington, R. W. (1971). Channel catfish virus: a new herpesvirus of Ictalurid fish. J. Virol. 8 (4): 525-533

Wolf, K., Gravell, M., Malsberger, R. G. (1966). Lymphocystis virus: isolation and propagation in a centrarchid fish cell line. Science 151. 1004-1005

Manuscript first received: March 10, 1992 Revised version accepted: June 23, 1992 